Reseña

\section{Carlos Larrinaga (ed.). Luis Bolín y el turismo en España entre 1928 y 1952. Madrid, Marcial Pons, 2021, 224 pp. ISBN: 978-8413811086.}

El estallido de la pandemia provocada por la COVID-19 ha hundido a la economía española en una crisis de una magnitud muy superior a la de la primera gran recesión del siglo XXI. Uno de los sectores más afectados ha sido precisamente el turístico, gran pilar de nuestra economía desde mediados del siglo xx, y que hasta hace pocos años no había despertado mucho interés en los historiadores económicos de nuestro país pese a su importancia crucial en las cuentas nacionales. De hecho, las últimas publicaciones en materia de historia del turismo han ubicado a España entre las naciones emergentes turísticamente del primer tercio del siglo xx. Obras como las dirigidas por Rafael Vallejo y Carlos Larrinaga, Los orígenes del turismo moderno en España. El nacimiento de un país turístico, 1900-1939, que recogen el fruto de varias investigaciones realizadas por especialistas en distintos ámbitos de la materia, han puesto de manifiesto esa precocidad española en el mercado turístico mundial. La obra Luis Bolín y el turismo en España entre 1928 y 1952 es también fruto de una colaboración multidisciplinar en la que los investigadores han elegido la figura de Luis Bolín para realizar un repaso por la historia turística española desde sus primeros tiempos en el Patronato de Nacional de Turismo (PNT) hasta comienzos de la década de 1950. El libro se estructura en seis capítulos elaborados por María José Rodríguez Pérez, Carlos Larrinaga, Carmelo Pellejero, Marta Luque, Beatriz Correyero Ruiz, Saida Palou Rubio y Carmen Gil de Arriba. Los cuatro primeros siguen un orden cronológico acorde con el currículo turístico de Luis Antonio Bolín Bidwell, mientras que los dos últimos se apartan de la senda común para acercarnos a la organización administrativa turística en Barcelona a través de las juntas provinciales de turismo y a alguna de las actuaciones estelares de Bolín al frente de la Dirección General de Turismo.

Este personaje, malagueño de buena familia, con buen dominio del inglés y estudios universitarios en Londres, así como bien relacionado con las élites, resulta conocido por el papel jugado en la Guerra Civil. Siendo corresponsal del diario $A B C$ en la capital británica, recibió una llamada del director del periódico para que alquilase un avión que debía trasladar a Franco al norte de África para iniciar la sublevación en julio de 1936. Conocemos su labor durante el conflicto y la posterior al frente de la Dirección General de Turismo a través de sus memorias y otras obras de su puño y letra. En cambio, sus años como subdelegado del Patronato Nacional de Turismo para la quinta región -Andalucía, Canarias y protectorado español de Marruecos- resultan más desconocidos. Aquí radica uno de los aciertos de esta nueva publicación, dado que María José Rodrí- guez Pérez reconstruye la dinámica de la gestión turística desempeñada por Bolín al frente de la quinta región empleando fuentes inéditas como las recogidas en los fondos del Archivo General de la Administración española. El paso de Bolín por el Patronato, una organización mediatizada por las élites aristocráticas, será productivo pero breve. Con la proclamación de la II República se suprime la Delegación de Andalucía en 1931 y Bolín es cesado. Retoma su trabajo de periodista en Londres y se dedica a escribir artículos de corte antirrepublicano hasta la llamada telefónica de Juan Ignacio Luca de Tena. Su apoyo a Franco será recompensado con la jefatura del Servicio Nacional de Turismo -en la zona controlada por el Gobierno de Burgos-. La finalidad de este servicio estaba clara para Bolín: se trataba de obtener divisas que la llegada de turistas extranjeros proporcionaría, mientas se realizaba una labor propagandística notable a favor del ejército sublevado para contrarrestar la campaña de propaganda internacional contra el bando franquista realizada por el Gobierno de Madrid. Finalizada la guerra, Bolín se coloca al frente de la Dirección General de Turismo, puesto que ocupará hasta comienzos de la década de 1950, cuando se crea el Ministerio de Información y Turismo y el personalismo de Bolín ya no tiene cabida en la nueva organización turística, como afirma Beatriz Correyero.

Pese a la escasez de recursos presupuestarios, tanto durante como después de la Guerra Civil, en el libro quedan patentes los logros en materia turística de ese gestor en un contexto nacional e internacional tremendamente desfavorable, pese a que, hasta no hace muchos años, esta se creía una etapa vacía de contenido turístico por la penuria económica de la postguerra y el ostracismo internacional de los primeros años del régimen dictatorial. Este constituye otro de los grandes méritos de la publicación. En paralelo, esta también apunta hacia algunas cuestiones turísticas que merecerían mayor espacio en el texto (o posteriores): aquellos territorios y empresas y empresarios que sacaron provecho de la promoción turística realizada desde los organismos públicos. La obra nos indica aquellas iniciativas en las que el Estado actuó directamente como agente empresarial y varias privadas beneficiadas directamente por su actuación. Precisamente, incluso algunos miembros de la familia Bolín se implicaron en el negocio turístico. Aquí consideramos necesario un futuro esfuerzo adicional a la hora de ubicar y cuantificar el destino del apoyo público dirigido a los intereses empresariales privados. Por ejemplo, conocer en la medida que las fuentes lo permitan quiénes fueron los principales destinatarios del Crédito Hotelero. Resulta llamativo observar cómo determinadas actuaciones del PNT, y posteriormente de los organismos sucesores, favorecieron a empresarios turísticos afines a la Dictadura de Primo de Rivera. Por ejemplo, algunas subvenciones y créditos del Patronato se destinaron a impulsar iniciativas en materia de hotelería de lujo, contribuyendo a la formación de un patrimonio turístico que benefició a las élites. 
En el primer franquismo observamos actitudes similares: contratos publicitarios de elevada cuantía con agencias nacionales y extranjeras, recién nacidas empresas de transporte con el fin de mejorar las comunicaciones y el acceso a los circuitos turísticos, nuevos créditos hoteleros, etc. Resulta también evidente, como señalan los autores en el capítulo dos, que serían necesarios estudios de conjunto para evaluar la influencia de los intereses organizados en la formación de la política turística del primer franquismo porque, a pesar del impacto de la guerra sobre el sistema turístico español, este no se destruyó al completo y Bolín se apoyó en el establecido durante la Dictadura de Primo de Rivera y la II República -hoteleros, agencias de viajes de Cook y Cafranga, entre otros-.

Elvira Lindoso Tato Universidade da Coruña

https://doi.org/10.33231/j.ihe.2022.01.011 